\title{
PENGARUH KUALITAS PELAYANAN TERHADAP KEPUASAN KONSUMEN PADA BISNIS JASA TRANSPORTASI GOJEK DI BANDAR LAMPUNG
}

\author{
Nur Satria ${ }^{(1)}$, Trisnowati Josiah ${ }^{(2)}, \operatorname{Kuswarak}^{(3)}$ \\ Fakultas Ekonomi Universitas Sang Bumi Ruwa Jurai \\ satria.nur28@gmail.com,trisnowati.josiah@fe.saburai.ac.id,kuswarak@fe.saburai.ac.id
}

\begin{abstract}
Abstrak. Jasa transportasi yang memiliki pelayanan yang cepat dari segi komunikasi untuk pemesanan, sehingga masyarakat lebih memilih jasa tersebut karena cukup mudah dan cepat. Untuk mendapatkan loyalitas para pelanggan perusahaan harus memiliki strategi pemasaran yang baik dan tepat agar mempengaruhi loyalitas pelanggannya. Faktor-faktor yang mempengaruhi loyalitas pelanggan dalam menggunakan jasa transportasi, diantaranya adalah kualitas pelayanan yang diberikan, kepuasan yang didapatkan dan dirasakan oleh pelanggan, nilai yang difikirkan pelanggan. Hasil penelitian didapatkan bahwa berdasarkan hasil Uji $\mathrm{t}$ didapat nilai $\mathrm{t}$ hitung $=20,177$ dan setelah dibandingkan dengan $\mathrm{t}$ tabel pada taraf signifikan 95\% yaitu 2,66, maka $\mathrm{t}$ hitung $=20,177>\mathrm{t}$ tabel $=2,66$. Jadi variabel kualitas pelayanan $(\mathrm{X})$ berpengaruh terhadap variabel kepuasan konsumen $(\mathrm{Y})$. Kemudian pada persamaan regresi antara variabel kualitas pelayanan $(\mathrm{X})$ terhadap variabel kepuasan konsumen $(\mathrm{Y})$ adalah $\mathrm{Y}=0,154+0,990 \mathrm{X}$. penjelasannya adalah : bo $=0,154$ merupakan nilai konstanta atau yang dapat diartikan bahwa kualitas pelayanan bernilai konstan sebesar satu point, berakibat kepuasan konsumen akan meningkat sebesar $0,154 \%$. Bx $=0,990$ yang dapat dinyatakan bahwa setiap penambahan tanggapan responden mengenai kualitas pelayanan, maka dapat diikuti oleh kepuasan kosnumen sebesar 99,0\% atau setiap terjadi peningkatan nilai pada variabel kualitas pelayanan sebesar satu point, maka kepuasan konsumen akan meningkat sebesar 0,990 point.
\end{abstract}

Kata kunci: Kepuasan, Konsumen, Kualitas, Pelayanan.

\section{PENDAHULUAN}

Seiring dengan berkembangnya zaman yang semakin cepat dan kemajuan dalam pendidikan serta perekonomian yang lebih makmur, perubahan sosial budaya masyarakat, serta perkembangan ilmu pengetahuan dan teknologi yang canggih, sarana transportasi dan komunikasipun semakin mudah sehingga membuat aktivitas manusia semakin cepat dan praktis.

Di era modern seperti saat ini alat transportasi dan komunikasi tidak bisa dipisahkan dari kehidupan manusia. Karena dua hal tersebut sering digunakan untuk mempermudah segala pekerjaan manusia. Kecanggihan alat transportasi di abad 21 tidak dapat terbendung lagi. Hal ini terbukti dengan adanya berbagai bidang seperti dari bidang komunikasi. Pemanfaatan teknologi bukan hanya di bidang komunikasi saja tetapi teknologi dimanfaatkan pada bidang pendidikan, ekonomi, pertanian, keamanan, transportasi dan lain-lain.

Perkembangan zaman yang makin pesat, semakin hari manusia semakin kreatif dan inovatif menciptakan bisnis baru, terutama bisnis yang menyediakan jasa transportasi. Karena manusia pada zaman sekarang membutuhkan transportasi yang cepat, nyaman, aman dan mudah ditemukan. Didaerah perkotaan seperti kota Bandar Lampung yang cukup luas dan penduduknya yang lumayan padat, kemacetan sering terjadi dan masyarakat banyak yang menggunakan kendaraan pribadi sehingga memicu kemacetan tersebut. Dan untuk masyarakat yang menggunakan transportasi umum lebih 
jenuh ketika menghadapi kemacetan yang terjadi.

Dengan bermunculan berbagai masalah transportasi, semakin banyak pula bisnis sektor jasa transportasi yang berpeluang untuk berbisnis, seperti bisnis dalam skala besar taxi, bus sampai skala kecil becak motor, angkot ataupun ojek pangkalan. Untuk memenuhi kebutuhan akan jasa transportasi tersebut, perlu adanya penyedia jasa yang memberikan pelayanan yang baik dan inovatif. Inovasi bukanlah hanya sekedar proses penciptaan sesuatu yang baru, tetapi dia juga merupakan produk actual atau outcome (hasil). Bagi bisnis penghasil jasa, outcome bukan hasil output, akan tetapi modifikasi dari pelayanan yang sudah ada. Sehingga perusahaan jasa transportasi membuat inovasi yang mempermudah masyarakat serta mempersingkat waktu perjalanan.

Jasa transportasi yang memiliki pelayanan yang cepat dari segi komunikasi untuk pemesanan, sehingga masyarakat lebih memilih jasa tersebut karena cukup mudah dan cepat. Untuk mendapatkan loyalitas para pelanggan perusahaan harus memiliki strategi pemasaran yang baik dan tepat agar mempengaruhi loyalitas pelanggannya. Faktor-faktor yang mempengaruhi loyalitas pelanggan dalam menggunakan jasa transportasi, diantaranya adalah kualitas pelayanan yang diberikan, kepuasan yang didapatkan dan dirasakan oleh pelanggan, nilai yang difikirkan pelanggan.

Suatu perusahaan yang mampu memberikan pelayanan yang baik kepada pelanggan akan membuat citra positif bagi perusahaan. Pelayanan yang baik mendorong minat pelanggan untuk menggunakan kembali jasa tersebut sehingga tercipta loyalitas. Perusahaan yang menjualkan jasa berarti menjualkan produknya dalam bentuk kepercayaan.

Memberikan pelayanan terbaik untuk konsumen menjadi tolak ukur keberhasilan sebuah perusahaan. Perusahaan yang berhasil memasarkan produk/jasanya kepada konsumen dengan pelayanan yang memuaskan mendapatkan brand yang baik dimata konsumen. Pelayanan yang dimaksud termasuk dari pelayanan sewaktu menawarkan produk/jasa, pelayanan ketika memberikan jasa, pelayanan atas resiko yang terjadi saat memberikan jasa dan pelayanan lain sebagainya.

Loyalitas pelanggan juga dapat terbentuk dari kepuasan yang dirasakan adalah perasaan senang ataupun kecewa yang muncul setelah menggunakan jasa tersebut. Pelanggan akan merasa senang dan kecewa setelah membandingkan kinerja atau hasil produk yang difikirkan terhadap kinerja (hasil) yang diharapkan. Dalam artian lain, seseorang merasa puas apabila hasil yang didapat minimal mampu memenuhi harapannya sedangkan seseorang merasa tidak puas apabila hasil yang didapat tidak mampu memenuhi harapannya. Kepuasan yang dirasakan seseorang akan memberikan dampak terhadap perilaku pengguna kembali secara terus-menerus sehingga terbentuklah loyalitas.

GO-JEK adalah sebuah perusahaan yang bergerak dibidang pelayanan transportasi ojek. Yang bertujuan untuk menghubungkan ojek dengan penumpang ojek. Perusahaan ini berdiri pertama kali di kota Jakarta pada tahun 2011. GO-JEK merupakan perusahaan yang berjiwa sosial yang memimpin revolusi industri transportasi Ojek. Karena efektifitas tujuan perusahaan ini yang bermitra kepada pengendara Ojek yang berpengalaman semakin baik dan meningkatnya peminat pelanggan sehingga GO-JEK dikembangkan di kota-kota besar lainnya seperti khususnya daerah JABODETABEK, Bandung, Medan, Surabaya, Bali, Bandar Lampung, Palembang dan kota-kota lainnya. 
Kehadiran PT GO-JEK Indonesia di kota Bandar Lampung pada tahun 2016 lalu, sejak kehadiran GO-JEK di kota Bandar Lampung menjadi alat alternative masyarakat untuk bepergian. GO-JEK menjadi solusi utama dalam pengiriman barang, pesan antar makanan, dan bepergian ketika macet. Konsumen merasa lebih mudah dan cepat memakai GO-JEK dengan harga yang terjangkau.

Aplikasi GO-JEK juga dapat diunduh pada smartphone yang memiliki sistem operasi iOS atau pun Android. Dengan menggunakan aplikasinya di smartphone pelanggan dapat diantar dan dijemput sesuai tujuan. Selain itu GO-JEK juga menyediakan layanan lainnya seperti GORIDE dan GO-CAR layanan transportasi, GO-FOOD yang dapat menjemput makanan dari cafe atau tempat makan yang tersedia, GO-MART yang digunakan untuk membelanjakan kebutuhan sehari-hari, GOBOX dan GO-SEND layanan kurir instan dan layanan yang belum tersedia di kota Bandar Lampung GO-GLAM, GO-CLEAN dan GO-MASSAGE.

Untuk saat ini GO-JEK tidak asing lagi di telinga masyarakat perkotaan khususnya kota Bandar Lampung, sehingga penyedia jasa ini ingin membuat pelanggannya merasa nyaman dan puas. Jika konsumen puas dan nyaman, maka mereka akan menggunakan jasa ini berulang kali sampai bisa menjadi pelanggan setia (loyal customer) sehingga perusahaan GOJEK menjadi market leader dan perusahaan ini menjadi perusahaan yang maju serta dipercaya oleh pelanggan di Indonesia. Persaingan GOJEK menjadi pro-kontra pada jasa transportasi umum lainnya seperti angkot, bis umum, becak motor dan transportasi online lainnya seperti Uber-Car dan Grab.

Persaingan ini menuai kontroversi terutama pada pihak ojek pangkalan yang melakukan aksi swepping pada pengemudi ojek online dan taksi online. Pihak ojek pangkalan merasa kehilangan pelanggan setelah hadirnya GOJEK dikota Bandar Lampung sehingga mereka melakukan aksi dan tindakan anarkis tersebut. Adanya persaingan ini, GOJEK Indonesia tetap memberikan pelayanan yang memuaskan pelanggan. Agar pelanggan dapat menikmati dengan senang dan merasa puas serta muncul loyalitas pelanggan terhadap GOJEK.

Setiap konsumen ingin mendapatkan pelayanan terbaik dari perusahaan yang menawarkan jasa kepadanya, dengan pelayanan yang baik dari penawar jasa maka konsumen akan merasa puas. Kepuasan yang dirasakan konsumen membuat konsumen ingin terus menerus memakai produk/jasa tersebut dalam jangka panjang. Sehingga perusahaan dituntut untuk memberikan kualitas pelayanan yang baik kepada setiap konsumennya.

\section{KAJIAN TEORI}

\section{Pengertian Jasa}

Menurut Kotler, jasa adalah tindakan yang ditawarkan oleh satu pihak kepada pihak lain yang pada dasarnya tidak berwujud dan tidak berakibat pada kepemilikan atas sesuatu. Menurut Stanton pengertian jasa adalah sebagai kegiatan yang didefinisikan secara tersendiri yang pada hakikatnya bersifat tak memiliki wujud (intangible), yang merupakan pemenuhan kebutuhan yang tidak terikat pada penjualan atau jasa lainnya.

Jasa merupakan aktivitas menawarkan produk yang tak berwujud namun dapat dirasakan hasilnya. Yang melibatkan dengan pelanggan atau pemilik pelanggan yang tidak berpengaruh kepada pemindahan kepemilikan. Jasa adalah sesuatu yang diberikan satu pihak kepada pihak lain yang pada dasarnya tidak berwujud dan tidak mengakibatkan terjadinya perpindahan kepemilikan. Stanton mengatakan bahwa 
"Service are identifiable, intangible activities that are main object of transaction designed to provide wantsatisfaction to costumer".

Menurut Kotler (2010 : 110), jasa memiliki 4 ciri utama yang sangat mempengaruhi rancangan program pemasaran, yaitu :

1. Tidak Berwujud (Intangibility)

Jasa mempunyai sifat tak berwujud, karena tidak bisa dilihat, dirasakan, diraba, didengar atau dicium sebelum ada transaksi pembelian. Untuk mengurangi ketidakpastian, pembeli akan mencari tanda atau bukti dari mutu jasa tersebut. Pembeli akan mengambil kesimpulan mengenai mutu jasa dari tempat (place), manusia (people), peralatan (equipment), alat komunikasi (communication material), simbolsimbol (symbols), dan harga (price) yang mereka lihat.

2. Tidak Dapat Dipisahkan (Inseparability) Jasa-jasa umumnya diproduksi secara khusus dan dikonsumsi pada waktu yang bersamaan. Jika jasa diberikan oleh seseorang, maka orang tersebut merupakan bagian dari jasa tersebut. Client juga hadir pada saat jasa diberikan, interaksi penyedia client merupakan ciri khusus dari pemasaran jasa tersebut.

\section{Beraneka Ragam (Variability)}

Jasa itu sangat beraneka ragam, karena tergantung kepada yang menyediakannya dan kapan serta dimana disediakan. Sering kali pembeli jasa menyadari akan keanekaragaman ini dan membicarakannya dengan yang lain sebelumm memilih seorang penyedia jasa.

\section{Tidak Tahan Lama (Perishability)}

Jasa-jasa tidak dapat disimpan. Keadaan tidak tahan dari jasa-jasa bukanlah masalah jika permintaanya stabil, karena mudah untuk melakukan persiapan pelayanan sebelumnya. Jika permintaan terhadapnya berfluktuasi maka perusahaan jasa menghadapi masalah yang sulit.

\section{Pengertian Kualitas Pelayanan}

Menurut Tjiptono kualitas pelayanan adalah upaya penyampaian jasa untuk memenuhi kebutuhan dan keinginan pelanggan serta ketepatan penyampaian untuk mengimbangi harapan pelanggan. Harapan konsumen merupakan keyakinan konsumen sebelum mencoba atau membeli suatu produk yang dijadikan acuan dalam menilai kinerja produk tersebut.

Menurut Lewis dan Booms, kualitas pelayanan sebagai ukuran seberapa bagus tingkat layanan yang diberikan mampu sesuai dengan harapan pelanggan. Adanya faktor yang mempengaruhi kualitas pelayanan yaitu jasa yang diharapkan dan jasa yang dirasakan atau dipersepsikan.

Apabila jasa yang diharapkan, maka kualitas pelayanan tersebut akan dipersepsikan baik atau positif. Jika jasa yang dipersepsikan melebihi jasa yang diharapkan, maka kualitas jasa dipersepsikan sebagai kualitas ideal.Demikian juga sebaliknya apabila jasa yang dipersepsikan lebih jelek dibandingkan dengan jasa yang diharapkan, maka kualitas jasa dipersepsikan negatif atau buruk. Maka baik tidaknya kualitas pelayanan tergantung pada kemampuan penyedia jasa dalam memenuhi harapan pelanggan secara konsisten.

Kualitas pelayanan menjadi suatu keharusan yang harus dilakukan perusahaan supaya mampu bertahan dan tetap mendapat kepercayaan pelanggan. Pola konsumsi dan gaya hidup pelanggan menuntut perusahaan mampu memberikan pelayanan yang berkualitas. Keberhasilan perusahaan dalam memberikan pelayanan 
yang berkualitas dapat ditentukan dengan pendekatan service quality yang telah dikembangkan oleh Parasuraman. Service quality adalah seberapa jauh perbedaan antara harapan dan kenyataan para pelanggan atas pelayanan yang mereka terima. Service quality dapat diketahui dengan cara membandingkan persepsi pelanggan atas pelayanan yang benarbemar mereka terima dengan layanan sesungguhnya yang mereka harapkan. Kualitas pelayanan menjadi hal pertama yang diperhatikan serius oleh perusahaan, yang melibatkan seluruh sumber daya yang dimiliki perusahaan.

Dalam perspektif TQM (Total Quality Manajemen), kualitas dipandang secara luas dimana tidak hanya aspek hasil saja yang ditekankan, melainkan juga meliputi proses lingkungan dan manusia sebagaimana dikemukakan oleh Gotesh dan Davis bahwa kualitas merupakan suatu kondisi dinamis yang berhubungan dengan produk, jasa, manusia, proses dan lingkungan yang memenuhi dan melebihi harapan.

\section{Pengertian Kepuasan Konsumen}

Kepuasan adalah perasaan senang atau kecewa yang berasal dari perbandingan antara kesannya terhadap kinerja atau hasil suatu produk dan harapan-harapannya. Dari definisi di atas, kepuasan merupakan fungsi dari persepsi atau kesan atas kinerja dan harapan. Jika kinerja berada dibawah harapan, pelanggan tidak puas. Jika kinerja memenuhi harapan, pelanggan puas. Jika kinerja melebihi harapan, pelanggan amat sangat puas. Apabila perusahaan menfokuskan pada kepuasan tinggi maka para konsumen yang kepuasannya hanya pas, akan mudah untuk berubah pikiran bila mendapat tawaran yang lebih baik.

Sedangkan konsumen yang amat puas lebih sukar untuk mengubah pilihannya. Kepuasan tinggi atau kesenangan yang tinggi menciptakan kelekatan emosional terhadap merek tertentu, bukan hanya kesukaan atau preferensi rasional dan hasilnya adalah kesetiaan konsumen yang tinggi. Menurut Umar Husein (2000 : 25) dalam menentukan tingkat kepuasan konsumen terdapat lima faktor utama yang harus diperhatikan oleh perusahaan, yaitu :

1. Kualitas produk, konsumen akan merasa puas bila hasil evaluasi mereka menunjukkan bahwa produk yang mereka gunakan berkualitas.

2. Kualitas pelayanan, terutama untuk industri jasa. Konsumen akan merasa puas bila mereka mendapatkan pelayanan yang baik atau yang sesuai dengan yang diharapkan.

3. Emosional, konsumen akan merasa bangga dan mendapatkan keyakinan bahwa orang lain akan kagum terhadap dia bila menggunakan produk dengan merek tertentu yang cenderung mempunyai tingkat kepuasan yang lebih tinggi.

4. Harga, produk yang mempunyai kulaitas yang sama tetapi menetapkan harga yang reltif murah akan memberikan nilai yang lebih tinggi kepada konsumennya.

5. Biaya, konsumen yang tidak perlu mengeluarkan biaya tambahan atau tidak perlu membuang waktu untuk mendapatkan suatu produk atau jasa cenderung puas terhadap produk atau jasa itu.

\section{Pengertian Harga}

Harga merupakan unsur bauran pemasaran yang sifatnya fleksibel dimana setiap saat dapat berubah menurut waktu dan tempatnya. Harga bukan hanya angkaangka yang tertera dilabel suatu kemasan atau rak toko, tapi harga 
mempunyai banyak bentuk dan melaksanakan banyak fungsi. Sewa rumah, uang sekolah, ongkos, upah, bunga, tarif, biaya penyimpanan, dan gaji semuanya merupakan harga yang harus anda bayar untuk mendapatkan barang atau jasa.

Menurut Kotler dan Armstrong (2012) yang dimaksud harga adalah "The amount of money charged for a product or service, the sum of the values that customers exchange for the benefit of having or using the product or service". Sedangkan harga menurut Morissan (2010) yaitu "mengacu pada apa yang harus diberikan konsumen untuk membeli suatu barang atau jasa yang biasanya menggunakan nilai uang”.

Kotler dan Keller (2012), menyatakan harga harus mencerminkan nilai konsumen bersedia membayar harga dibandingkan harus mencerminkan hanya biaya pembuatan produk atau memberikan layanan. Artinya harga merupakan sejumlah uang yang dibutuhkan atau ditukarkan ke konsumen untuk mendapatkan atau memiliki suatu barang yang memiliki manfaat serta penggunaannya.

\section{METODE PENELITIAN}

\section{Objek Penelitian}

Penelitian ini dilaksanakan di Kantor Jasa Transportasi GO-JEK yang beralamat di Jalan M. Husni Thamrin No. 77, Gotong Royong, Tanjung Karang Pusat, Kota Bandar Lampung Kode Pos 35214. Perusahaan ini bergerak dalam bidang transportasi GOJEK. Penelitian dilaksanakan pada bulan April 2019 sampai dengan Juni 2019.

\section{Metode dan Teknik Pengumpulan Data}

Dalam penelitian ini jenis data yang diperlakukan adalah :

a. Data Primer
Data primer merupakan data dasar yang akan diperoleh langsung tanpa perantara orang atau lembaga lain sebagai pihak ketiga. Data primer ini diperoleh dengan wawancara melalui responden dengan menggunakan daftar pertanyaan.

b. Data Sekunder

Data skunder merupakan data yang diperoleh melalui orang lain yang berhubungan dengan permasalahan yang dipecahkan. Data sekunder ini diperoleh melalui cara studi dokumenter yaitu mengumpulkan dan mempelajari brosurbrosur serta dokumen organisasi.

Adapun teknik yang digunakan dalam pengumpulan data adalah dengan :

1. Observasi, yaitu mengadakan survey atau pengamatan langsung kelokasi penelitian.

2. Interview atau wawancara, yaitu mengadakan tanya jawab langsung dengan pegawai.

3. Dokumentasi, yaitu mengumpulkan dan mencatat dokumentasi yang relevan.

4. Kuisioner, yaitu membuat pertanyaan yang berhubungan dengan varibael penelitian.

\section{Sampel dan Populasi}

Teknik pengumpulan data dalam penelitian ini akan menggunakan pengambilan responden secara keseluruhan atau populasi. Menurut Nanang Martono (2011) mendefinisikan populasi adalah seluruh objek atau subjek yang berada pada suatu wilayah dan memenuhi syarat-syarat tertentu berkaitan dengan masalah penelitian, atau keseluruhan unit atau individu dalam ruang lingkup yang akan diteliti. Adapun populasi dalam penelitian ini adalah karyawan dan konsumen Konsumen GO-JEK di Bandar Lampung sebanyak 30 orang, kemudian menurut Suharsimi Arikunto (2013) apabila objek 
penelitian lebih dari 100 maka lebih baik diambil sebagian yang besar 15 hingga 20 persen untuk dijadikan sebagai sampel.

\section{Metode Analisis Data}

Analisis kualitatif yaitu menganalisa permasalahan dengan cara membandingkan antara teori dengan permasalahan yang dihadapi oleh Transportasi Jasa GO-JEK di Bandar Lampung, yaitu mengenai kualitas pelayanan.

Analisis kuantitatif berupa persamaan Regresi Linear Sederhana menentukan persamaan regresi linear sederhana untuk $\mathrm{X}$ dengan rumus, yaitu:

$$
Y=a+b X+e
$$

Keterangan:

$$
\begin{aligned}
& \mathrm{Y}=\text { Kepuasan konsumen } \\
& \mathrm{a}=\text { Konstanta } \\
& \mathrm{b}=\text { Koefisien regresi } \mathrm{X} \\
& \mathrm{X}=\text { Kualitas pelayanan } \\
& \mathrm{e}=\text { Faktor kesalahan }
\end{aligned}
$$

Untuk mengetahui besarnya pengaruh, penghitungan koefisien korelasi tersebut kemudian dilanjutkan dengan Rumus Koefisien Determinasi atau Koefisien Penentu (KP):

$$
K P=(r)^{2} x 100 \%
$$

Untuk menguji secara hipotesis secara parsial digunakan Uji t dengan rumus :

$$
t_{\text {hitung }}=\frac{r \sqrt{N-2}}{\sqrt{1-r^{2}}}
$$

Keterangan:

$$
\begin{aligned}
& \mathrm{t}_{\text {hitung }} \quad=\text { Nilai } \mathrm{t} \\
& \mathrm{r}=\text { Koefisien Korelasi } \\
& \mathrm{N} \quad=\text { Jumlah responden }
\end{aligned}
$$

Kriteria untuk Uji $\mathrm{t}$ adalah sebagai berikut :

a) Jika $t_{\text {hitung }}>t_{\text {tabel }}$ maka Ha diterima dan Ho ditolak.

b) Jika $t_{\text {hitung }} \leq \mathrm{t}_{\text {tabel }}$ maka Ha ditolak dan Ho diterima.

\section{HASIL DAN PEMBAHASAN}

\section{Uji Validitas dan Reliabilitas}

Uji validitas dilakukan untuk mengukur valid tidaknya suatu instrumen. Uji validitas dilakukan dengan menggunakan teknik korelasi Pearson Moment. Uji validitas digunakan untuk menguji sejauh mana suatu alat pengukur dapat mengukur atau mengungkapkan konsep gejala/kejadian yang diukur. Item kuesioner dinyatakan valid apabila nilai $r$ hitung $>\mathrm{r}$ tabel $(\mathrm{n}-2)$. Pengujian validitas selengkapnya dapat dilihat pada Tabel 1 .

Tabel 1. Hasil Pengujian Validitas

\begin{tabular}{lllll}
\hline No. & Variabel & $\mathbf{r}_{\text {hitung }}$ & $\mathbf{r}_{\text {tabel }}$ & Keterangan \\
\hline 1 & Kualitas & & & \\
& Pelayanan & & & \\
& X.1 & 0.886 & 0,318 & Valid \\
& X.2 & 0.758 & 0,318 & Valid \\
& X.3 & 0.777 & 0,318 & Valid \\
& X.4 & 0.680 & 0,318 & Valid \\
& X.5 & 0.379 & 0,318 & Valid \\
& X.6 & 0.562 & 0,318 & Valid \\
X.7 & 0.260 & 0,318 & Invalid \\
& X.8 & 0.228 & 0,318 & Valid \\
X.9 & 0.562 & 0,318 & Valid \\
& X.10 & 0.638 & 0,318 & Valid \\
Kepuasan & & & \\
Konsumen & & & \\
Y.1 & 0.878 & 0,318 & Valid \\
Y.2 & 0.741 & 0,318 & Valid \\
Y.3 & 0.821 & 0,318 & Valid \\
Y.4 & 0.656 & 0,318 & Valid \\
Y.5 & 0.423 & 0,318 & Valid \\
Y.6 & 0.696 & 0,318 & Valid \\
Y.7 & 0.330 & 0,318 & Valid \\
Y.8 & 0.420 & 0,318 & Valid \\
Y.9 & 0.424 & 0,318 & Valid \\
Y.10 & 0.580 & 0,318 & Valid \\
\hline & & & &
\end{tabular}


Berdasarkan data pada Tabel 1. terlihat bahwa korelasi antara masing-masing indikator terhadap total skor konstruk dari setiap variabel menunjukkan hasil yang signifikan dan hanya satu pada variabel kualitas pelayanan yang lebih kecil, sehingga menunjukkan bahwa $\mathrm{r}$ hitung $>\mathrm{r}$ tabel. atau dapat disimpulkan bahwa hampir semua item pertanyaan dinyatakan valid.

Uji Reliabilitas (keterpercayaan) yang dipergunakan adalah untuk mengetahui layak tidaknya data responden yang digunakan dalam penelitian. Untuk uji relaibilitas ini digunakan Teknik Aplha Cronbach, dimana suatu instrumen dikatakan handal (reliabel) bila memiliki koefisien keandalan atau alpha sebesar 0,5 atau lebih. (Sugiono, 2003). Reliabilitas pernyataan variabel Kualitas Pelayanan dengan jumlah responden ( $N$ of Cases) sebesar 40 dan jumlah item pernyataan $(N$ of items) alpha total sebesar 0,768. dari 10 item pertanyaan nilai alpha of item deleted seluruhnya menunjukkan reliabel, karena nilai 10 item pernyataan lebih dari 0,665 .

\section{Analisis Kuantitatif}

Berdasarkan hasil Uji t didapat nilai $\mathrm{t}$ hitung $=20,177$. Apabila dibandingkan dengan $\mathrm{t}$ tabel pada taraf signifikan 95\% yaitu 2,66, maka $\mathrm{t}$ hitung $=20,177>\mathrm{t}$ tabel $=$ 2,66 sehingga dapat disimpulkan bahwa : Ha yang menyatakan terdapat pengaruh antara variabel kualitas pelayanan (X) terhadap kepuasan konsumen (Y) dapat diterima. Jadi variabel kualitas pelayanan (X) berpengaruh terhadap variabel kepuasan konsumen (Y).

Sedangkan berdasarkan hasil penelitian, diperoleh koefisien determinasi kualitas pelayanan terhadap kepuasan konsumejn adalah sebagai berikut :

Apabila merujuk dari hasil pembahasan berkenaan dengan pengaruh antara kualitas pelayanan dan kepuasan konsumen pada bisnis jasa transportasi Gojek di Bandar
Lampung dimana berdasarkan hasil Uji t didapat nilai $\mathrm{t}$ hitung $=20,177$ dan setelah dibandingkan dengan $\mathrm{t}$ tabel pada taraf signifikan $95 \%$ yaitu 2,66, maka $\mathrm{t}$ hitung $=$ 20,177> $\mathrm{t}$ tabel $=2,66$ sehingga dapat disimpulkan bahwa : Ha yang menyatakan terdapat pengaruh antara variabel kualitas pelayanan (X) terhadap kepuasan konsumen (Y) dapat diterima. Jadi variabel kualitas pelayanan (X) berpengaruh terhadap variabel kepuasan konsumen (Y).

Menurut besarnya nilai $t$ hitung $=20,177$ adalah karena kualitas pelayanan pada bisnis jasa transportasi Gojek di Bandar Lampung ini terkesan lemah dan kalaupun ada pengaruh kualitas pelayanan terhadap kepuasan konsumen baru menampakkan peningkatan. Hal ini dibuktikan dengan perhitungan pada Koefisien Determinasi $=$ $\mathrm{R}^{2}=0,953^{2}=0,909=0,909 \times 100=90,9 \%$. Dapat disimpulkan bahwa variabel kepuasan konsumen menjelaskan variasi perubahan terhadap variabel kualitas pelayanan pada bisnis jasa transportasi Gojek di Bandar Lampung sebesar 90,9\%.

Sedangkan sisanya dijelaskan oleh faktor lain yang tidak dapat dikaji dalam penelitian ini dan persamaan regresi antara variabel kualitas pelayanan (X) terhadap variabel kepuasan konsumen (Y) adalah Y $=0,154+0,990 \mathrm{X}$ penjelasannya adalah $:$ bo $=0,154$ merupakan nilai konstanta atau yang dapat diartikan bahwa kualitas pelayanan bernilai konstan, maka bila setiap terjadi peningkatan nilai pada variabel kualitas pelayanan sebesar satu point, berakibat kepuasan konsumen hanya akan meningkat sebesar $0,154 \%$.

$\mathrm{Bx}=0,990$ yang dapat dinyatakan bahwa setiap penambahan tanggapan responden mengenai kualitas pelayanan, maka dapat diikuti oleh kepuasan konsumen sebesar satu point, maka kepuasan konsumen akan meningkat sebesar 0,990 point, artinya kualitas pelayanan akan berjalan baik jika kepuasan konsumen baik dan ini akan meningkatkan 
point sebesar 0,990. Bila kualitas pelayanan baik, maka setidaknya kepuasan konsumen pada bisnis jasa transportasi Gojek di Bandar Lampung dapat berjalan dengan baik.

\section{KESIMPULAN DAN SARAN}

\section{Kesimpulan}

Dari pembahasan yang telah diuraikan, maka dapat ditarik kesimpulan bahwa berdasarkan hasil $\mathrm{Uji} \mathrm{t}$ didapat nilai $\mathrm{t}$ hitung $=$ 20,177 dan setelah dibandingkan dengan $\mathrm{t}$ tabel pada taraf signifikan $95 \%$ yaitu 2,66, maka $\mathrm{t}$ hitung $=20,177>\mathrm{t}$ tabel $=2,66$ sehingga dapat disimpulkan bahwa : Ha yang menyatakan terdapat pengaruh antara variabel kualitas pelayanan (X) terhadap kepuasan konsumen (Y) dapat diterima. Jadi variabel kualitas pelayanan (X) berpengaruh terhadap variabel kepuasan konsumen (Y). Kemudian pada persamaan regresi antara variabel kualitas pelayanan (X) terhadap variabel kepuasan konsumen (Y) adalah $\mathrm{Y}=0,154+0,990 \mathrm{X}$ penjelasannya adalah : bo $=0,154$ merupakan nilai konstanta atau yang dapat diartikan bahwa kualitas pelayanan bernilai konstan sebesar satu point, berakibat kepuasan konsumen akan meningkat sebesar $0,154 \%$. $\mathrm{Bx}=0,990$ yang dapat dinyatakan bahwa setiap penambahan tanggapan responden mengenai kualitas pelayanan, maka dapat diikuti oleh kepuasan kosnumen sebesar 99,0\% atau setiap terjadi peningkatan nilai pada variabel kualitas pelayanan sebesar satu point, maka kepuasan konsumen akan meningkat sebesar 0,990 point.

\section{Saran}

Berdasarkan kesimpulan yang telah dilakukan maka dalam penelitian ini yang dapat diberikan sebagai saran yaitu :
1. Hendaknya kondisi yang dicapai oleh perusahaan pada saat ini terus dipertahankan dimasa-masa mendatang.

2. Hendaknya perusahaan terus memberikan pengarahan-pengarahan kepada tukang ojek online dalam hal ini Gojek agar dapat meningkatkan pelayanannya.

3. Hendaknya perusahaan memberikan reward bagi tukang ojek online yang berprestasi khususnya yang menggunakan aplikasi Gojek.

\section{DAFTAR PUSTAKA}

Adam, M. 2015. Manajemen Pemasaran Jasa. Bandung: Alfabeta.

Alma, Buchari. 2011. Manajemen

Pemasaran Dan Pemasaran Jasa. Bandung: Alfabeta.

Assauri, S. 2015. Manajemen Pemasaran. Jakarta: PT Raja Grafindo Persada.

Aswawi, N. dan Masyhuri. 2009. Metodologi Riset Manajemen Pemasaran. UINMalang: UIN-Malang Press.

Bungin, Burhan. 2008. Metodologi Penelitian Kuantitatif. Jakarta: Kencana.

Ginting, Nembah F. H. 2011. Manajemen Pemasaran, Bandung: Yrama Widya.

Hafidhudin, D. 2003. Manajemen Syariah Dalam Praktik, Jakarta: Gema Insani Press.

Hasan, Ali. 2013. Marketing dan Kasus-Kasus Pilihan, Jogjakarta: Cups Publishing. 
Irawan, Handi. 2009. 10 Prinsip Kepuasan Pelanggan, Jakarta: PT Elex Media Komputindo Gramedia.

Karim. Adiwarman A. 2003. Bank Islam: Analisis Fiqih Dan Keuangan, Jakarta: IIIT Indonesia.

Kottler, P \& Keller, K. L. 2010. Manajemen Pemasaran (13 ed.). Jakarta: Erlangga.

Nur, J. 2012. Metodologi Penelitian Skripsi, Thesis, Disertasi dan Karya Ilmiah. Jakarta: Kencana.

Nur, M. 2004. Manajemen Jasa Terpadu. Bogor: Ghalia Indonesia.

Qardawi, Yusuf. 2007. Norma Dan Etika Ekonomi Islam, Jakarta: GIP.

Setiyanto, D. A. 2016. Sebuah Catatan Sosial Tentang Ilmu, Islam, Dan Indonesia, Yogjakarta: Deepublish. 